\title{
Co-regulated expression of matrix metalloproteinase-2 and transforming growth factor- $\beta$ in melanoma development and progression
}

\author{
GRAZIA MALAPONTE ${ }^{1}$, ALESSANDRA ZACCHIA ${ }^{1}$, YLENIA BEVELACQUA ${ }^{2}$, ANDREA MARCONI ${ }^{1}$, \\ ROSARIO PERROTTA ${ }^{2}$, MARIA CLORINDA MAZZARINO ${ }^{1}$, VERA CARDILE ${ }^{3}$ and FRANCA STIVALA ${ }^{1}$ \\ ${ }^{1}$ Department of Biomedical Sciences, ${ }^{2}$ Plastic Surgery Section, Department of Medicine and Surgery Specialities, Azienda \\ Ospedaliera Cannizzaro; ${ }^{3}$ Department of Physiological Sciences, University of Catania, Catania, Italy
}

Received February 23, 2010; Accepted March 18, 2010

DOI: $10.3892 /$ or_00000831

\begin{abstract}
Previous studies have found that matrix metalloproteinase-2 (MMP-2) and transforming growth factor- $\beta$ (TGF-B) can be considered as biomarkers and indices of disease progression in several human cancers. In this study, we investigated the plasma levels of MMP-2 and TGF- $\beta$ and their correlation in 49 primary cutaneous melanoma and 10 metastatic melanoma. Plasma MMP-2 and TGF- 3 levels in patients with primary melanoma were significantly higher than those of healthy controls. These protein levels were significantly higher in patients with metastatic melanoma. A positive correlation between plasma levels of MMP-2 and TGF- $\beta$ in melanoma patients supports the hypothesis that TGF- $\beta$ triggers the release of MMP-2. The immunohistochemistry analysis shows that MMP-2 and TGF- 3 were highly expressed in tumor tissues as well as in matched plasma samples. This finding suggests that these proteins are released from tumor cells. Overall, our data indicate that MMP-2 and TGF- $\beta$ may represent novel diagnostic markers and therapeutic targets in melanoma and the determination of their concentration could be a useful diagnostic and prognostic indicator. TGF- $\beta$, leading the tissue invasion mediated by MMP-2, is a strong promoter of tumor progression. Therefore, reducing or blocking the activity of TGF- $\beta$ may represent a promising target in therapeutic strategies for limiting the growth of melanoma.
\end{abstract}

\section{Introduction}

Melanoma is one of the most aggressive human malignancies and its incidence is steadily increasing throughout the world. In melanoma, prognostic markers are needed that would help to refine the risk of progression, assess the clinical outcome

Correspondence to: Dr Grazia Malaponte, Dipartimento di Scienze Biomediche, Università di Catania, Via Androne 83, 95123 Catania, Italy

E-mail: g.malaponte@unict.it

Key words: MMP-2, TGF-ß, cytokines, melanoma and select optimal treatment strategies (1-3). In normal epithelial cells, transforming growth factor- $\beta$ (TGF- $\beta$ ) acts as a strong inhibitor of cell growth (4).

During tumorigenesis, transformed epithelial cells frequently escape from TGF- $\beta$-induced growth control; and once this has occurred, TGF- $\beta$ can act as a promoter of tumor progression $(5,6)$. TGF- $\beta$ may then affect the plasticity and adhesion of tumor cells and induce tumor cell migration $(7,8)$.

In melanoma, high TGF- $\beta$ expression is correlated with a more aggressive phenotype and increased local infiltration, suggesting that TGF- $\beta$ may also stimulate the invasion of tumor cells to promote tumor progression (9-11).

TGF- $\beta$ up-regulates the matrix metalloproteinase- 2 (MMP-2), acting as a strong autocrine mediator of tumor cell invasion and degrading proteinases (12-14). After the components of the extracellular matrix (ECM) are degraded, tumor cells invade the surrounding tissue and the vascular or lymphatic vessels to form metastatic colonies at distant sites. Increased expression of matrix metalloproteinases (MMPs) renders the tumor cells capable of digesting essential tissue barriers especially basement membranes lining the blood vessels, thereby promoting cell motility $(15,16)$.

Expression of MMP-2 protein was found to be correlated with decreased architectural organization, increased atypia and haematogenous metastasis (17-19). High expression and activation levels of TGF- $\beta$ and MMP-2 can be considered as biomarkers and indices of disease progression in several types of human cancers (20-23). Although, it has been demonstrated that TGF- $\beta$ and MMP- 2 are expressed in melanoma $(10,11,24,25)$, no evidence has been shown on their correlation with clinic pathologic features in melanoma patients.

We analyzed the circulating plasma levels and immunohistochemistry (IHC) expression of TGF- 3 and MMP-2 in human melanoma patients, with tumor chara-cteristic compared with controls.

\section{Patients and methods}

Plasma and tissues. Plasma obtained from 59 patients with cutaneous malignant melanoma at different stages of disease and healthy controls, matched in age and sex, were provided by 
Table I. Socio-demographic and clinical characteristics of patients with melanoma and control subjects.

\begin{tabular}{|c|c|c|c|c|c|}
\hline & \multicolumn{2}{|c|}{ Cases of melanoma } & \multicolumn{2}{|c|}{ Controls } & \multirow[b]{2}{*}{$\chi^{2}$} \\
\hline & $\mathrm{n}$ & $(\%)$ & $\mathrm{n}$ & $(\%)$ & \\
\hline \multicolumn{6}{|l|}{ Sex } \\
\hline Male & 36 & $(61)$ & 14 & $(40)$ & \\
\hline Female & 23 & (39) & 21 & $(60)$ & $\mathrm{p}=0.05$ \\
\hline \multicolumn{6}{|l|}{ Age (years) } \\
\hline$\leq 55$ & 25 & $(42.4)$ & 22 & $(62.8)$ & \\
\hline$>55$ & 34 & $(57.6)$ & 13 & $(37.2)$ & $\mathrm{p}=0.05$ \\
\hline \multicolumn{6}{|l|}{ Type of cancer } \\
\hline Primary cutaneous melanoma & 49 & $(83)$ & & & \\
\hline Metastatic melanoma & 10 & (17) & & & \\
\hline \multicolumn{6}{|l|}{ Type of primary melanoma } \\
\hline Superficial spreading & 23 & $(46.9)$ & & & \\
\hline Nodular & 26 & $(53.1)$ & & & \\
\hline \multicolumn{6}{|l|}{ Breslow thickness } \\
\hline$\leq 2.0$ & 25 & $(51)$ & & & \\
\hline$>2.0$ & 24 & (49) & & & \\
\hline \multicolumn{6}{|l|}{ Clark's level } \\
\hline I-II & 30 & $(61.2)$ & & & \\
\hline III-IV & 19 & $(38.8)$ & & & \\
\hline \multicolumn{6}{|l|}{ Ulceration of primary melanoma } \\
\hline Absent & 27 & $(55.1)$ & & & \\
\hline Presente & 22 & $(44.9)$ & & & \\
\hline Not assessable & 0 & & & & \\
\hline \multicolumn{6}{|l|}{ Sentinel lymph node } \\
\hline Negative & 26 & (53) & & & \\
\hline Positive & 23 & $(47)$ & & & \\
\hline
\end{tabular}

the Section of Plastic and Reconstructive Surgery, University of Catania, and collected at the Department of Biomedical Sciences, University of Catania. Healthy controls were recruited from among the institute personnel and all were in excellent health at the time of the study. Clinical staging of patients were performed on a pathological basis according to the new American Joint Committee on Cancer 2001 classification system (26).

Tumor biopsy specimens were analyzed from all 59 melanoma patients. Among these, 49 patients showed primary melanoma, at different stages (ranging from 0.1 to $15.9 \mathrm{~mm}$ in thickness, Clark's level II-V); 10 melanoma patients showed metastatic disease with predominantly lymph node involvement. As control groups, 35 healthy controls and 15 benign melanocytic nevi (BMN) tissue samples were used. Each patient gave informed consent for the use of biological material for research purposes.

The socio-demographic characteristics of cases and controls and the distribution of cases of melanoma, according to clinical features at diagnosis, are shown in Table I.

Measurement of MMP-2 and TGF- $\beta$ proteins. Circulating MMP-2 and TGF- $\beta$ levels were quantitatively analyzed by solid-phase enzyme linked immunosorbent assay (ELISA), using specific commercial kits (R\&D Systems Europe Ltd., Abingdon, UK). Were prepared 7 scale dilutions of the standard solution included in the kit. Each sample was tested in duplicate. Spectrophotometer reading at $450 \mathrm{~nm}$ was performed by EIA reader (Opsys, MR, ThermoLab System, Franklin, MA, USA) and, considering the optical density, it was possible to detect the concentration of the related proteins in question. The detection limit of MMP-2 and TGF- $B$ is 0.047 and $4.61 \mathrm{pg} / \mathrm{ml}$, respectively.

Immunohistochemical staining. After fixation in $10 \%$ buffered formaldehyde, the processing of sample and immunohistochemical (IHC) procedures were done according to the instructions of the manufacturer. Expression of MMP-2 and TGF- $\beta$ was assessed using a standard streptavidinbiotinylated peroxidase (HRP) complex method on an automated platform. Mouse monoclonal anti-MMP-2 (R\&D Systems) and mouse monoclonal anti-TGF- $\beta$ antibody (Santa Cruz Biotechnology, Inc.) were used for detected the immunohistochemical expression on serial sections of melanoma.

Statistical analysis. Statistical analysis was performed using SPSS software, version 12.0. The differences in plasma levels of MMP-2 and TGF- $\beta$ were analyzed using the Wilcoxon's 

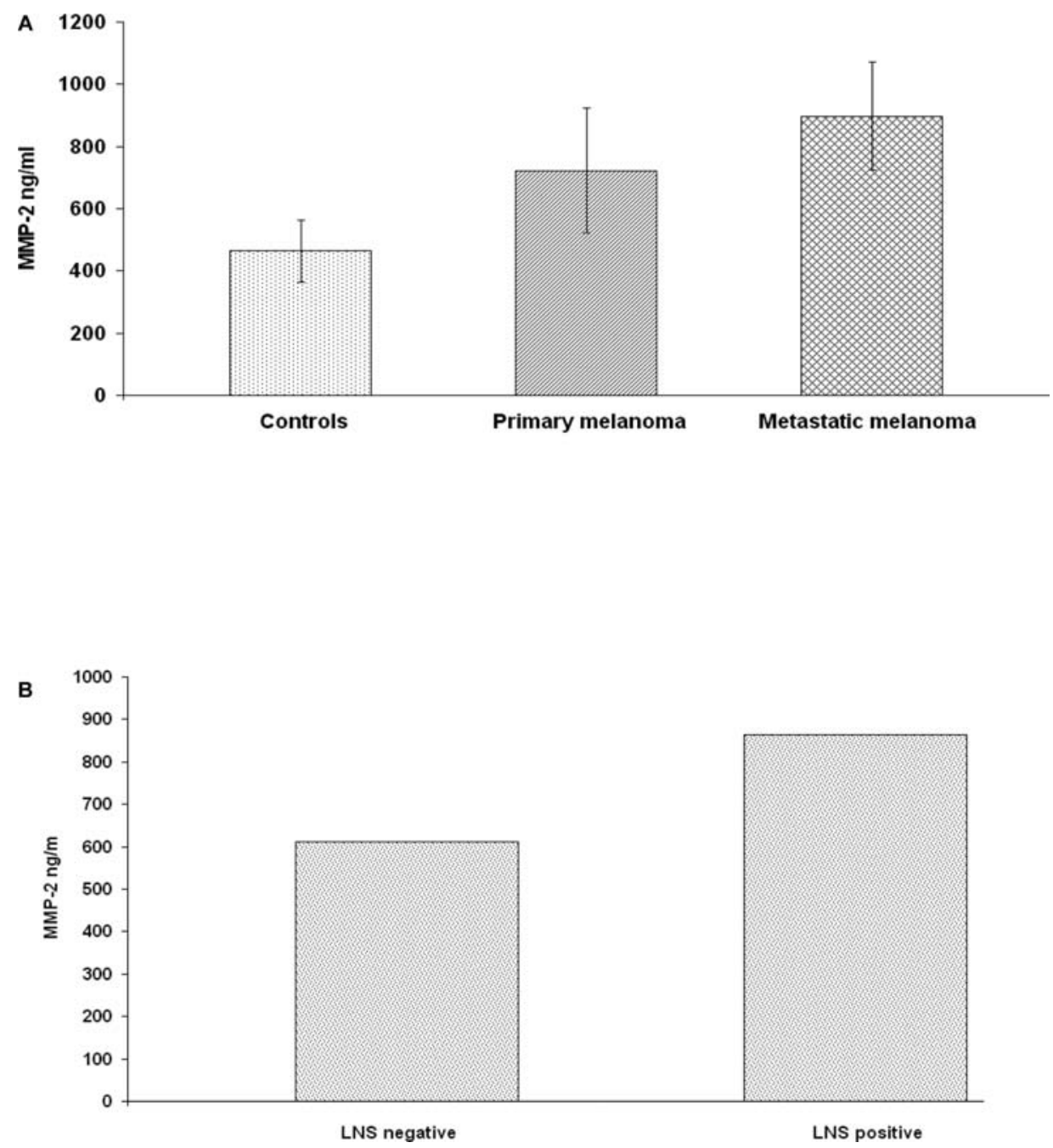

Figure 1. MMP-2 plasma levels in melanoma patients. (A) MMP-2 plasma levels in primary and metastatic melanoma patients; (B) MMP-2 plasma levels in melanoma patients with negative and positive sentinel lymph-nodes.

signed ranks test. Comparison of socio-demographic and clinical characteristics between healthy controls and melanoma patients was performed with the $\chi^{2}$ test. Correlation between MMP-2 and TGF- $\beta$ was calculated with two-sided Spearman rank correlation test. $\mathrm{P}<0.05$ was regarded as significant.

\section{Results}

Plasma levels of MMP-2. The plasma levels of MMP-2 in primary and metastatic melanoma and in healthy controls are shown in the Fig. 1. Patients with metastases had a higher level of MMP-2 than patients without metastasis (mean, 898 vs. $722 \mathrm{ng} / \mathrm{ml} ; \mathrm{p}=0.008$ ) and healthy controls (mean, 898 vs. $464 \mathrm{ng} / \mathrm{ml} ; \mathrm{p}<0.0001$ ) (Fig. 1A). In primary melanoma these levels remain statistically higher than in healthy controls $(\mathrm{p}<0.0001)$. Moreover, among melanoma patients at different Clark levels, there was no statistically significant difference of MMP-2 plasma levels $(\mathrm{p}=0.5)$. Increased levels of MMP-2 were observed according to Breslow thickness, although no statistic significance was observed $(\mathrm{p}=0.09)$. In contrast, significant difference was found in patients with positive vs. negative sentinel lymph node melanoma ( $\mathrm{p}=0.009)$ (Fig. 1B).
Plasma levels of TGF- $\beta$. The plasma levels of TGF- $\beta$ in primary melanoma, metastatic melanoma and in TGF- $\beta$ healthy controls are shown in Fig. 2. A statistically significant difference was noted between the patients with primary melanoma and healthy controls. Higher plasma TGF- $\beta$ levels was found in melanoma patients than in controls (mean, 301 vs. $195.7 \mathrm{pg} / \mathrm{ml} ; \mathrm{p}<0.0001)$. Patients with metastatic melanoma showed a higher level of TGF- $\beta$, statistically significant, compared with patients with primary melanoma (mean, 374 vs. $301 \mathrm{pg} / \mathrm{ml} ; \mathrm{p}=0.03$ ) and healthy controls (mean, 374 vs. $195.7 \mathrm{pg} / \mathrm{ml} ; \mathrm{p}<0.0001$ ) (Fig. 2A). In addition, median TGF- $\beta$ plasma determinations showed significant difference among patients with positive vs. negative sentinel lymph nodes melanoma $(\mathrm{p}<0.0001)$ (Fig. $2 \mathrm{~B})$, at different Clark stages $(\mathrm{p}<0.005)($ Fig. $2 \mathrm{C})$ and at high Breslow thickness $(>2)$ vs. low Breslow thickness $(<2)(\mathrm{p}<0.01)$ (Fig. 2D).

Correlation between plasma MMP-2 and TGF- $\beta$ levels and the clinicopathological characteristics of patients with melanoma. Table II shows a positive correlation between plasma MMP-2 and TGF- $\beta$ levels in melanoma patients. As expected, this correlation is very high in the group of patients with primary 

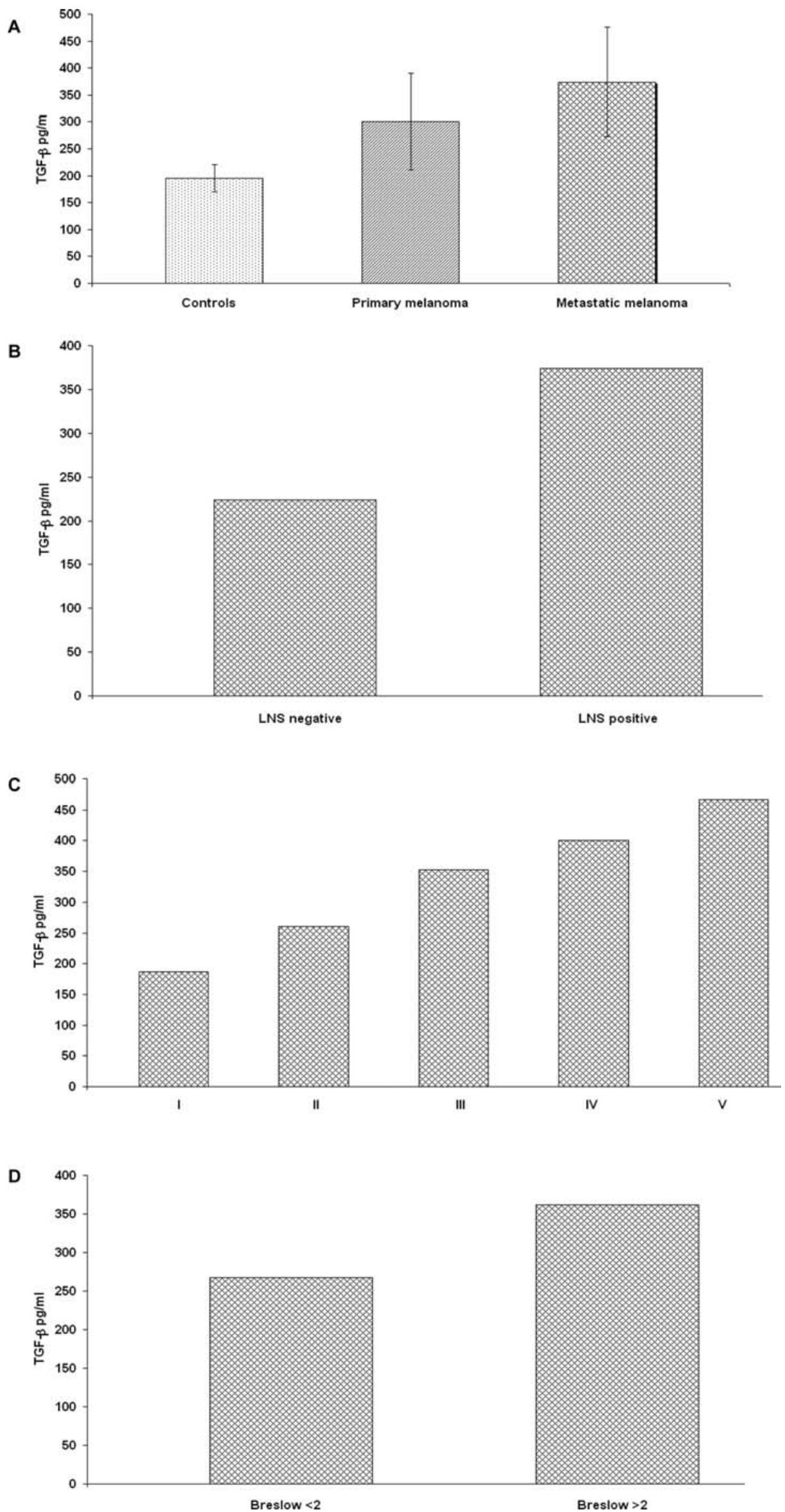

Figure 2. TGF- $\beta$ plasma levels in melanoma patients. (A) TGF- $\beta$ plasma levels in primary and metastatic melanoma patients; (B) TGF- $\beta$ plasma levels in melanoma patients with negative and positive sentinel lymph nodes; (C) TGF-ß plasma levels in melanoma patients with different Clark's levels; (D) TGF-ß plasma levels in melanoma patients with different Breslow thickness. 
Table II. Correlation between plasma MMP-2 and TGF- 3 level in melanoma patients.

\begin{tabular}{|c|c|c|c|c|c|}
\hline \multirow[b]{2}{*}{ MMP-2 } & \multicolumn{2}{|c|}{ Primary melanoma } & \multicolumn{3}{|c|}{ Metastatic melanoma } \\
\hline & $\begin{array}{c}\text { MMP-2 } \\
\text { r } \\
-\end{array}$ & $\begin{array}{c}\text { TGF- } \beta \\
\mathrm{r} \\
0.54(\mathrm{p}<0.001)\end{array}$ & $\begin{array}{c}\text { MMP-2 } \\
\text { r } \\
-\end{array}$ & $\begin{array}{r}\mathrm{TG} \\
0.61(\mathrm{p}\end{array}$ & $\begin{array}{l}\mathrm{JF}-\beta \\
\mathrm{r} \\
<0.001)\end{array}$ \\
\hline \multicolumn{6}{|l|}{ A. } \\
\hline \multicolumn{3}{|c|}{ Clinical characteristics } & $\begin{array}{l}\text { MMP-2 } \\
<700\end{array}$ & $\begin{array}{c}\text { MMP-2 } \\
\geq 700\end{array}$ & P-value \\
\hline $\begin{array}{l}\text { Sex } \\
\text { Male } \\
\text { Female }\end{array}$ & & & $\begin{array}{r}16 \\
8\end{array}$ & $\begin{array}{l}15 \\
10\end{array}$ & 0.48 \\
\hline $\begin{array}{l}\text { Age (yea } \\
\leq 57 \\
>57\end{array}$ & ars) & & $\begin{array}{r}10 \\
4\end{array}$ & $\begin{array}{r}16 \\
9\end{array}$ & 0.11 \\
\hline $\begin{array}{r}\text { Primary } \\
\text { Positiv } \\
\text { Negati }\end{array}$ & $\begin{array}{l}\text { cutaneous } \\
\text { e sentine } \\
\text { ve sentin }\end{array}$ & $\begin{array}{l}\text { melanoma } \\
\text { lymph node } \\
\text { lymph node }\end{array}$ & $\begin{array}{r}6 \\
18\end{array}$ & $\begin{array}{r}17 \\
8\end{array}$ & 0.003 \\
\hline $\begin{array}{l}\text { Clark's le } \\
\text { I-II } \\
\text { III-IV }\end{array}$ & evel & & $\begin{array}{r}17 \\
7\end{array}$ & $\begin{array}{l}13 \\
12\end{array}$ & 0.1 \\
\hline $\begin{array}{c}\text { Breslow } \\
\leq 2.00 \\
>2.00\end{array}$ & thickness & $(\mathrm{mm})$ & $\begin{array}{r}16 \\
9\end{array}$ & $\begin{array}{r}17 \\
7\end{array}$ & 0.6 \\
\hline $\begin{array}{r}\text { Ulceratio } \\
\text { Absent } \\
\text { Present } \\
\text { Not ass }\end{array}$ & $\begin{array}{l}\text { of of prim } \\
t \\
\text { sessable }\end{array}$ & lary melanoma & $\begin{array}{r}11 \\
11 \\
0\end{array}$ & $\begin{array}{r}13 \\
14 \\
0\end{array}$ & 0.9 \\
\hline
\end{tabular}

B.

\begin{tabular}{lrrr}
\hline & $\begin{array}{r}\text { TGF- } \beta \\
\text { Clinical characteristics }\end{array}$ & $\begin{array}{c}\text { TGF- } \beta \\
\geq 286\end{array}$ & P-value \\
\hline Sex & 15 & 16 & 0.9 \\
$\quad$ Male & 9 & 9 & \\
$\quad$ Female & & & \\
Age (years) & 13 & 13 & 0.87 \\
$\quad \leq 57$ & 11 & 12 & \\
$\quad$ 57 & & & \\
Primary cutaneous melanoma & 4 & 19 & 0.0001 \\
$\quad$ Positive sentinel lymph node & 20 & 6 & \\
$\quad$ Negative sentinel lymph node & & & \\
Clark's level & & 9 & 0.001 \\
I-II & 21 & 15 & \\
III-IV & 4 & & \\
Breslow thickness (mm) & & & \\
$\quad \leq 2.00$ & 15 & 10 & 0.06 \\
$\quad$ 2.00 & 8 & 16 & \\
Ulceration of primary melanoma & & & \\
$\quad$ Absent & 13 & 10 & 0.1 \\
Present & 9 & 17 & \\
$\quad$ Not assessable & 0 & 0 & \\
\hline
\end{tabular}

MMP-2, matrix metalloproteinase-2; TGF- $\beta$, transforming growth factor. Spearman rank correlation test. $\mathrm{P}<0.05$ was regarded as significant.
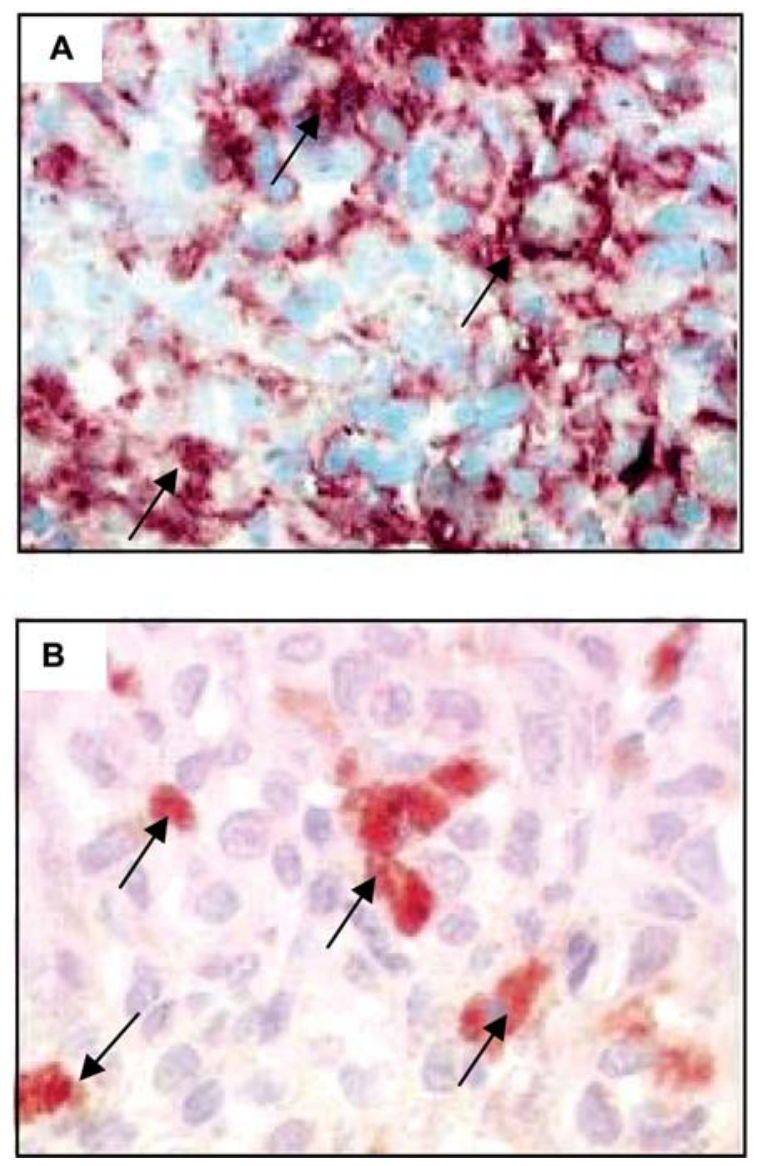

Figure 3. Immunohistochemistry evaluation of MMP-2 and TGF- $\beta$ in a representative cutaneous melanoma tissue sample.

melanoma $(r=0.53, p<0.001)$ and tends to be much higher in the metastatic group $(\mathrm{r}=0.61, \mathrm{p}<0.0001)$. No correlation was found in the control group (data not shown).

We then compared plasma MMP-2 and TGF- $\beta$ levels among primary melanoma patients with different clinicopathological features. The potential association of plasma MMP-2 and TGF- $\beta$ levels with different clinicopathological features was examined in patients stratified according to MMP-2 $(<700$ and $>700 \mathrm{ng} / \mathrm{ml})$ and TGF- $\beta(<286$ and $>286 \mathrm{pg} / \mathrm{ml})$ levels. Elevated MMP-2 (>700 ng/ml; Table IIA) and TGF- $\beta$ (>286 pg/ml; Table 2B) plasma concentrations were strongly associated with positive sentinel lymph nodes $(\mathrm{p}=0.003$, $\mathrm{p}=0.0001$; respectively). No association among sex, age, Breslow thickness, ulceration and MMP-2 and TGF- $\beta$ was found. However, only TGF- $\beta$ correlated with Clark's levels $(\mathrm{p}=0.001)$, in fact, we observed that TGF- $\beta$ concentration increased significantly with advanced Clark stages (stage II, $\mathrm{p}=0.015$; stage III, $\mathrm{p}=0.008$; stages IV $-\mathrm{V}, \mathrm{p}=0.005$; respectively). No association between MMP-2 and Clark's levels were found.

Immunohistochemical staining of MMP-2 and TGF- $\beta$ in melanoma lesions. To test whether the protein plasma levels of MMP-2 and TGF- $\beta$ derived from tumor cells, immunohistochemical staining was performed in cutaneous melanoma samples and in nevi. Overall, 38 of 49 primary tumors (77.5\%) expressed MMP-2 and TGF-B (Fig. 3). IHC analysis shows that both proteins were highly expressed in tumor tissues as 
well as in matched plasma samples. The intensity of staining in metastatic melanoma cells was stronger than that in primary lesions (data not shown). As expected, MMP-2 and TGF- $\beta$ immunohistochemical staining was negative in nevi samples.

\section{Discussion}

Recent studies strongly support the crucial role of TGF- $\beta$ in tumor progression through the regulation of MMP bioavailability. It was demonstrated that the release of TGF- $\beta$ in tumor microenvironment regulates pro-MMPs, triggering the secretion of these proteins, which intrinsically governs the behavior of various cells, leading to metastasis (12-14,21,27-30).

Many researchers have shown that TGF- $\beta$ induces the expression of MMPs (like MMP-2, MMP-9, MMP-10) in several human cancer cell lines, such as prostate (31), bladder (13), breast (32), endometrial (33), oral (29) and ovarian cancer (12). However, no previous study has investigated a possible correlation between serum levels of MMP-2 and TGF- $B$ in melanoma.

The results of the present study revealed that the plasma concentrations of both MMP-2 and TGF- $\beta$ were significantly higher in patients with melanoma than the concentration detected in healthy controls. In addition, patients with metastatic melanoma showed a higher level of MMP-2 and TGF- $\beta$, compared with patients with primary melanoma and healthy controls, suggesting its potential usefulness as a marker of melanoma progression. These findings are in agreement with several studies, documenting an increased expression and secretion of the different TGF- $\beta$ isoforms in melanoma cell lines when compared with normal melanocytes $(34,35)$. All these studies were inclined toward an increase in TGF- $\beta$ expression levels that correlates with tumor progression $(9,11)$. The disruption of some components of the TGF- $\beta$ signaling pathway is associated with the evolution of melanoma (36).

The results of the present study are also in agreement with several reports that have implicated MMP-2 in the regulation of tumor cell migration and adhesion $(19,20,37)$. Increased expression of MMP-2 was shown to correlate with an invasive phenotype $(38,39)$, in addition, in situ studies of human melanocytic lesions demonstrated that MMP-2 expression is increased with architectural disorder, atypia and progression to melanoma $(17,20,40)$.

The novelty of the present study is the documented concomitant increased plasma concentrations of TGF- $\beta$ and MMP-2 in melanoma patients. The combination of these proteins may be used as biomarkers to evaluate the aggressiveness of this pathological condition and may be helpful to monitor the efficacy of medical treatments.

Immunohistochemistry analysis was applied to discover the origin/source of both MMP-2 and TGF- $\beta$ melanoma samples. Our results show that these proteins are mostly released from tumor cells. These results are in agreement with previous data $(9,41-43)$ and further support the possibility that both markers are co-regulated in melanoma cells. The release and the expression of these proteins suggests that these circulating factors arise from tumor and probably accumulate as a result of an increased tumor burden in advanced stages of disease.

Based on the above, we believe that further studies focused on the reduction of MMP-2 expression by blocking the activity of TGF- $\Omega$ may represent promising therapeutic strategy for an otherwise devastating disease.

\section{References}

1. Singh H, Sethi S, Raber M and Petersen LA: Errors in cancer diagnosis: current understanding and future directions. J Clin Oncol 25: 5009-5018, 2007.

2. Utikal J, Schadendorf D and Ugurel S: Serologic and immunohistochemical prognostic biomarkers of cutaneous malignancies. Arch Dermatol Res 298: 469-477, 2007.

3. Gogas H, Eggermont AM, Hauschild A, et al: Biomarkers in melanoma. Ann Oncol 20 (Suppl. 6): vi8-13, 2009.

4. Alexandrow MG and Moses HL: Transforming growth factor beta and cell cycle regulation. Cancer Res 55: 1452-1457, 1995.

5. Wakefield LM and Roberts AB: TGF-beta signaling: positive and negative effects on tumorigenesis. Curr Opin Genet Dev 12: $22-29,2002$.

6. Akhurst RJ and Balwain A: Genetic events and the role of TGF- $\beta$ in epithelial tumor progression. Pathology 187: 82-90, 1999.

7. Oft M, Peli J, Rudaz C, Schwarz H, Beug H and Reichmann E: TGF- $B 1$ and Ha-Ras collaborate in modulating the phenotypic plasticity and invasiveness of epithelial tumor cells. Genes Dev 10: 2462-2477, 1996.

8. Cui W, Fowlis DJ, Bryson S, et al: TGF beta1 inhibits the formation of benign skin tumors, but enhances progression to invasive spindle carcinomas in transgenic mice. Cell 86: 531-542, 1996.

9. Reed JA, McNutt NS, Prieto VG and Albino AP: Expression of transforming growth factor-beta 2 in malignant melanoma correlates with the depth of tumor invasion. Implications for tumor progression. Am J Pathol 145: 97-104, 1994.

10. Javelaud D, Alexaki VI and Mauviel A: Transforming growth factor-beta in cutaneous melanoma. Pigment Cell Melanoma Res 21: 123-132, 2008.

11. Krasagakis K, Tholke D, Farthmann B, Eberle J, Mansmann U and Orfanos CE: Elevated plasma levels of transforming growth factor (TGF)-beta 1 and TGF-beta 2 in patients with disseminated malignant melanoma. Br J Cancer 77: 1492-1494, 1998.

12. Lin SW, Lee MT, Ke FC, et al: TGF-beta stimulates the secretion of matrix metalloproteinase 2 (MMP2) and the invasive behavior in human ovarian cancer cells, which is suppressed by MMP inhibitor BB3103. Clin Exp Metastasis 18: 493-499, 2000.

13. Dehnavi E, Soheili ZS, Samiei S, Ataei Z and Aryan H: The effect of TGF-beta2 on MMP-2 production and activity in highly metastatic human bladder carcinoma cell line 5637. Cancer Invest 27: 568-574, 2009.

14. Taipale J, Saharinen J and Keski-Oja J: Extracellular matrix associated transforming growth factor beta: role in cancer cell growth and invasion. Adv Cancer Res 75: 87-134, 1998.

15. Hofmann UB, Westphal JR, van Muijen GN and Ruiter DJ: Matrix metalloproteinases in human melanoma. J Invest Dermatol 115: 337-344, 2000.

16. Rundhaug JE: Matrix metalloproteinases and angiogenesis. J Cell Mol Med 9: 267-285, 2005.

17. Väisänen A, Tuominen H, Kallioinen $M$ and TurpeenniemiHujanen T: Matrix metalloproteinase-2 (72 kD type IV collagenase) expression occurs in the early stage of human melanocytic tumour progression and may have prognostic value. J Pathol 180: 283-289, 1996.

18. Hofmann UB, Westphal JR, Waas ET, Becker JC, Ruiter DJ and van Muijen GN: Coexpression of integrin alpha(v)beta3 and matrix metalloproteinase-2 (MMP-2) coincides with MMP-2 activation: correlation with melanoma progression. J Invest Dermatol 115: 625-632, 2000.

19. John A and Tuszynski G: The role of matrix metalloproteinases in tumor angiogenesis and tumor metastasis. Pathol Oncol Res 7: 14-23, 2001.

20. Hofmann UB, Westphal JR, Zendman AJ, Becker JC, Ruiter DJ and van Muijen GN: Expression and activation of matrix metalloproteinase-2 (MMP-2) and its co-localization with membranetype 1 matrix metalloproteinase (MT1-MMP) correlate with melanoma progression. J Pathol 191: 245-256, 2000. 
21. Ellenrieder V, Hendler SF, Ruhland C, Boeck W, Adler G and Gress TM: TGF-beta-induced invasiveness of pancreatic cancer cells is mediated by matrix metalloproteinase- 2 and the urokinase plasminogen activator system. Int J Cancer 93: 204-211, 2001.

22. Morton DM and Barrack ER: Modulation of transforming growth factor beta 1 effects on prostate cancer cell proliferation by growth factors and extracellular matrix. Cancer Res 55: 2596-2602, 1995.

23. Gorsch SM, Memoli VA, Stukel TA, et al: Immunohistochemical staining for transforming growth factor beta 1 associates with disease progression in human breast cancer. Cancer Res 52: 6949-6952, 1992.

24. Wollina U, Hipler UC, Knoll B, Graefe T, Kaatz M and Kirsc K: Serum matrix metalloproteinase-2 in patients with malignant melanoma. J Cancer Res Clin Oncol 127: 631-635, 2001.

25. Väisänen A, Kallioinen M, Taskinen PJ and TurpeenniemiHujanen T: Prognostic value of MMP-2 immunoreactive protein ( $72 \mathrm{kD}$ type IV collagenase) in primary skin melanoma. J Pathol 186: 51-58, 1998.

26. Balch CM, Buzaid AC, Soong SJ, et al: Final version of the American Joint Committee on Cancer staging system for cutaneous melanoma. J Clin Oncol 19: 3635-3648, 2001.

27. Iida J and McCarthy JB: Expression of collagenase-1 (MMP-1) promotes melanoma growth through the generation of active transforming growth factor-beta. Melanoma Res 17: 205-213, 2007.

28. Dang D, Yang Y, Li X, et al: Matrix metalloproteinases and TGFbeta1 modulate oral tumor cell matrix. Biochem Biophys Res Commun 316: 937-942, 2004

29. Sun L, Diamond ME, Ottaviano AJ, Joseph MJ, Ananthanarayan V and Munshi HG: Transforming growth factor-beta 1 promotes matrix metalloproteinase-9-mediated oral cancer invasion through snail expression. Mol Cancer Res 6: 10-20, 2008.

30. Wick W, Platten M and Weller M: Glioma cell invasion: regulation of metalloproteinase activity by TGF-beta. J Neurooncol 53: $177-185,2001$

31. Konrad L, Scheiber JA, Schwarz L, Schrader A and Hofmann R: TGF-beta1 and TGF-beta2 strongly enhance the secretion of plasminogen activator inhibitor-1 and matrix metalloproteinase-9 of the human prostate cancer cell line PC-3. Regul Pept 155: 28$32,2009$.
32. Kim ES, Kim MS and Moon A: TGF-beta-induced upregulation of MMP-2 and MMP-9 depends on p38 MAPK, but not ERK signaling in MCF10A human breast epithelial cells. Int J Oncol 25: 1375-1382, 2004.

33. Yabushita $\mathrm{H}$, Narumiya $\mathrm{H}$, Hiratake $\mathrm{K}$, et al: The association of transforming growth factor-beta 1 with myometrial invasion of endometrial carcinomas through effects on matrix metalloproteinase. J Obstet Gynaecol Res 26: 163-170, 2000.

34. Van Belle P, Rodeck U, Nuamah I, Halpern AC and Elder DE: Melanoma-associated expression of transforming growth factorbeta isoforms. Am J Pathol 148: 1887-1894, 1996.

35. Rodeck U, Bossler A, Graeven U, et al: Transforming growth factor beta production and responsiveness in normal human melanocytes and melanoma cells. Cancer Res 54: 575-581, 1994.

36. Hussein MR: Transforming growth factor-beta and malignant melanoma: molecular mechanisms. J Cutan Pathol 32: 389-395, 2005.

37. Curran S and Murray GI: Matrix metalloproteinases in tumor invasion and metastasis. J Pathol 189: 300-308, 1999.

38. Capon F, Emonard H, Hornebeck W, Maquart FX and Bernard P: Expression and activation of pro-gelatinase A by human melanoma cell lines with different tumorigenic potential. Clin Exp Metastasis 17: 463-469, 1999.

39. Kahari V and Saarialho-Kere U: Matrix metalloproteinases and their inhibitors in tumour growth and invasion. Ann Med 31: 34-45, 1999.

40. Redondo P, Lloret $\mathrm{P}$, Idoate $\mathrm{M}$ and Inoges $\mathrm{S}$ : Expression and serum levels of MMP-2 and MMP-9 during human progression. Clin Exp Dermatol 30: 541-545, 2005.

41. Vuoristo MS, Kellokumpu-Lehtinen P, Parvinen LM, et al: Serum matrix metalloproteinase-2 as a prognostic marker in advanced cutaneous melanoma. Acta Oncol 39: 877-879, 2000.

42. Simonetti O, Lucarini G, Brancorsini D, et al: Immunohistochemical expression of vascular endothelial growth factor, matrix metalloproteinase 2, and matrix metalloproteinase 9 in cutaneous melanocytic lesions. Cancer 95: 1963-1970, 2002.

43. Walker RA and Woolley DE: Immunolocalisation studies of matrix metalloproteinases-1, -2 and -3 in human melanoma. Virchows Arch 435: 574-579, 1999. 